\title{
JÚLIO MOREIRA FRAGATA OU UMA INICIAÇÃO NA FENOMENOLOGLA DE HUSSERL
}

\author{
Joaquim Carlos Araújo \\ Escola Secundária José Afonso - Loures
}

\section{Nota prévia}

Desejamos transformar este pequeno estudo numa oportunidade para fornecer, ao público leitor português menos versado nesta área, alguns elementos necessários a uma breve apresentação da fenomenologia do incontornável Edmund Husserl, baseando-nos, para isso, na tese de doutoramento do teólogo-filósofo Júlio Moreira Fragata, a saber, A Fenomenologia de Husserl como fundamento da Filosofia, defendida em 1954 na Universidade Gregoriana. ${ }^{1}$

Tal tese constitui-se como a única monografia que o professor escreveu sobre o assunto em análise, já que todas as suas publicações anteriores e posteriores foram feitas sob a forma de pequenos artigos ou coletâneas dos mesmos, como por exemplo Problemas de Fenomenologia de Husserl (1962). FHF talvez seja, assim, o primeiro grande livro de fôlego escrito em português e sistematicamente dedicado a tão complexo tema, ${ }^{2}$ tendo, eventualmente,

\footnotetext{
${ }^{1}$ A partir de agora FHF. Utilizámos a edição da Livraria Cruz / Faculdade de Filosofia de Braga, de 1983 (reprodução fotomecânica da edição de 1958).

2 Tendo também surgido por esta altura a primeira obra de Husserl vertida para a nossa língua por Albin Beau e precedida de um longo prefácio de Joaquim de Carvalho (datado de 1952), A Filosofia como Ciência de Rigor. Coimbra: Atlântida, MCMLXV (a tradução de Philosophie als strenge Wissenschaft, editada por Husserl no primeiro número da Revista Logos, em 1910-1911).Segundo o mesmo Joaquim de Carvalho: «A presente tradução é, pois, a primeira que destas páginas se faz em qualquer língua [...]» (p. IX). Existe no entanto uma primeira tradução castelhana de 1951: Edmund Husserl, La filosofia como ciencia estricta. Aus dem Deutschen übersetzt von J. Rovira Armengol. Buenos Aires: Facultad de Filosofia y Letras, 1951.
} 
sido pela pena do Padre Fragata que a academia filosófica portuguesa pôde pela primeira vez seriamente experimentar (e estudar na língua de Camões) o pensamento do filósofo nascido no dia 8 de abril de 1859, em Prossnitz (naMorávia), no antigo ImpérioAustríaco (hoje Prostejov, na República Checa).

Com uma riquíssima bibliografia cronologicamente orientada mas também com as datas das últimas redações das obras póstumas de Husserl, o autor, nas suas 62 referências aos originais alemães - além de outras 61 indicações gerais - estabeleceu uma valiosa lista de referência que terá sido repetidamente consultada pelas gerações seguintes.

Em termos temáticos o autor indica ainda, em nota explicativa da lista bibliográfica, as 4 fases do pensamento de Husserl:

a) a sua adesão ao psicologismo - do qual se afastará com a publicação das Investigações Lógicas (1900-1901);

b) a apresentação da fenomenologia sem a introdução do conceito de «epoché» - só introduzido a partir do curso $A$ ideia de fenomenologia (1907);

c) o problema da «constituição» e do «idealismo fenomenológico» - com Ideias (1913), Lógica formal e transcendental (1929) e a obra que Husserl considerou como a principal de toda a sua vida (em carta a Roman Ingarden), Meditações Cartesianas (1929), texto que entregou para ser traduzido para francês;

d) a aplicação da fenomenologia ao problema da vida concreta e da história, com a publicação da chamada Krisis - A crise das ciências europeias e a fenomenologia transcendental - Uma introdução à filosofia fenomenológica (1936).

Se desejássemos um subtítulo para o nosso texto deveríamos escrever: breve apresentação pedagógica da filosofia de Husserl. De facto privilegiaremos o escolar, o pedagógico, em detrimento do académico ou mesmo do estudo crítico - pelo menos na Parte I do presente estudo. Com este intuito, apresentaremos vários organogramas conceptuais, de modo a poder encontrar-se a génese e o funcionamento dos diversos conceitos da fenomenologia, seguindo aliás, pensamos, a própria intenção pedagógica do Professor Júlio Fragata que utiliza inclusive alguma exposição esquemática deste tipo, no livro que por agora ocupa as nossas reflexões. 


\section{A) Nota bio-bibliográfica ${ }^{3}$}

Júlio Moreira Fragata nasceu em Seixo de Ansiães (Bragança) a 17 de abril de 1920. Frequentou o Seminário da Costa (Guimarães) entre 1932 e 1937. Neste ano entrou na Companhia de Jesus e fez os estudos de Humanidades Clássicas em Guimarães e o Curso de Filosofia em Braga (1947). De 1945 a 1947, ensinou Grego e Matemáticas Gerais aos estudantes da Ordem, no Curso de Humanidades (em Guimarães). Em 1947 deu início aos estudos de teologia na Faculdade Teológica de Sarriá (em Barcelona). Manteve as suas investigações na Faculdade de Teologia da Universidade de Innsbruck (Áustria). É ordenado sacerdote a 25 de julho de 1950. Em 1951 obtém, nessa Faculdade, a licenciatura em teologia. Depois de um ano de estudos pastorais em St. Andrã (Klagenfurt, Áustria) doutorou-se, em 1954, com uma tese defendida na Universidade Gregoriana, A Fenomenologia de Husserl como Fundamento da Filosofia. De 1954 a 1965 assumiu a direção espiritual, no Centro Académico de Braga, para estudantes entre os 10 e os 18 anos. De 1954 a 1962 exerceu o cargo de ministro da classe dos estudantes jesuítas que frequentavam a Faculdade de Filosofia. De 1962 a 1964 desempenhou o oficio de ministro da casa (equivalente a subdiretor). A partir de 1954 começou a ensinar na Faculdade de Filosofia de Braga, tendo produzido obra sobretudo no âmbito da história da filosofia moderna e contemporânea. Neste último período até 1960 deu vários cursos no Centro de Estudos Humanísticos, anexo à Universidade do Porto, sobre temas relativos à história da filosofia, nomeadamente sobre filosofia moderna do renascimento; a Kant; sobre a fenomenologia de Husserl; sobre a filosofia da existência e sobre o materialismo dialético. A partir de 1965 exerce as funções de Responsabilizado pela Regência para a cadeira de história da filosofia moderna na Faculdade de Letras da Universidade do Porto. De julho a outubro de 1965, a convite da Faculdade de Filosofia de Nova Friburgo (Brasil), passou três meses no Brasil dando um curso de história da filosofia contemporânea nessa Faculdade. Na mesma ocasião proferiu várias conferências no Rio de Janeiro sobre fenomenologia e filosofia da existência, na Universidade do Brasil, na Universidade do Estado de Guanabara, na Pontifícia Universidade Católica, na sede da Sociedade Brasileira de Fenomenologia e no Instituto da Santa Úrsula. Desde 1962 pertenceu à Direção da secção de filosofia da Enciclopédia "Verbo", na qual colaborou assiduamente. Foi membro fundador do Centro de Estudos Fenomenológicos (1965, Coimbra) e fez parte da Direção,

${ }^{3}$ Fontes consultadas: www.bragancanet.pt (consultado em 2.02.2006); Enciclopédia Logos; Enciclopédia Luso-Brasileira. 
entre 1965 e 1985. De 1968 a 1971 foi Diretor da Faculdade de Filosofia da UCP e Reitor do Colégio Máximo. Tornou-se Presidente da Assembleia-geral da Associação Jurídica de Braga no tempo em que foi Diretor da Faculdade de Filosofia. De 1972 a 1977 foi Superior Provincial da Província Portuguesa da Companhia de Jesus. De 1978 a 1985 exerceu o cargo de Diretor da Faculdade de Filosofia de Braga, da Universidade Católica Portuguesa. Teve um papel preponderante no lançamento da Secção de Viseu da Universidade Católica Portuguesa e na Extensão madeirense (Funchal) desta Universidade, tendo sido Diretor de uma e de outra. Foi ainda professor de metodologia dos trabalhos científicos ${ }^{4}$ e de ontologia (Curso de Filosofia - extensão da Madeira). Orientou um curso para pós-graduados sobre Ontologia e Epistemologia. Em colaboração com Alexandre Fradique Morujão, Francisco da Gama Caeiro e António Paim orientou os trabalhos preparatórios da Enciclopédia de filosofia Logos (Editorial Verbo). Escreveu, inclusive, para a Enciclopédia Luso-Brasileira de Cultura. Na Revista Portuguesa de Filosofia publicou mais de uma centena de artigos, notas, crónicas e vocábulos. Elaborou inúmeras recensões bibliográficas e prefácios a livros. Colaborou em outras revistas e jornais.

Júlio Fragata, à semelhança de outros grandes vultos portugueses da Igreja Católica, trabalhou filosoficamente nas áreas da fenomenologia, do existencialismo e do marxismo, temas dominantes da época e de alguma forma solicitados no próprio Concílio do Vaticano II pelo Papa Paulo VI, que terá incumbido a Companhia de Jesus de dialogar com as novas correntes do pensamento. Faleceu em Braga, a 27 de dezembro de 1985. Muitos dos seus atuais discípulos revivem com prazer algumas das suas aulas magistrais.

\section{B) Alguns estudos fenomenológicos de Júlio Moreira Fragata}

1956 "Husserl e o fundamento das ciências". Revista Portuguesa de Filosofia $(R P F), 13$.

1959 A Fenomenologia de Husserl como Fundamento da Filosofia. Braga: Livraria Cruz.

1959 "Metafisica husserliana e metafisica tomista". $R P F, 15$.

1961 "O problema de Deus na fenomenologia de Husserl". $R P F, 17$.

1962 Problemas de Fenomenologia de Husserl. Braga: Livraria Cruz.

1962 "Fenomenologia e problema crítico". In: Problemas de Fenomenologia de Husserl. Braga: Livraria Cruz.

1962 “A filosofia de Husserl". In: Problemas de Fenomenologia de Husserl. Braga: Livraria Cruz.

\footnotetext{
${ }^{4}$ Veja-se com académico agrado a sua obra Noções de Metodologia-Para a Elaboração de um Trabalho Cientifico. Porto: Livraria Tavares Martins, Porto, 1973.
} 
1962 "O impulso psicológico da fenomenologia de Husserl". In: Problemas de Fenomenologia de Husserl. Braga: Livraria Cruz.

1962 "A fenomenologia como fundamento da filosofia". In: Problemas de Fenomenologia de Husserl. Braga: Livraria Cruz.

1965 "Husserl e a filosofia da existência". RPF, 21.

1965 "O conceito de ontologia em Husserl". In: Perspectivas da Fenomenologia de Husserl. Coimbra.

1982 "Uma interpretação do 'fenómeno puro' de Husserl como fundamentador". $R P F, 38$ (II).

1985 "Fenomenologia e gnoseologia". RPF, 41.

\section{Parte I}

\section{Apresentação fragatiana da Fenomenologia de Edmund Husserl (1859-1938)}

\section{§1. É possível encontrar um fundamento husserliano da filosofia?}

Constata-se logo à partida, no prólogo de FHF, que «quase não existe nenhum filósofo de fama universal sem a sua fenomenologia». Em boa verdade o autor o afirmou, já que dedicou alguma parte da sua vida ao estudo da obra original, publicada e inédita, do grande filósofo alemão falecido em Freiburg, em 27 de abril de 1938. Conhecedor do alemão e de várias línguas clássicas e contemporâneas, Júlio Fragata, igualmente apaixonado pelo rigor científico do pensamento, enceta a aventura de começar tudo de novo, ensaiando uma busca ao pensamento de Husserl para, com ele, tentar fundamentar do modo mais originário possível o conhecimento filosófico.

A partir do contexto da filosofia ensinada em Viena por Francisco Brentano, vemos o então jovem matemático Husserl ${ }^{5}$ a deixar enredar-se, durante dois anos, na magnífica diversidade dos sistemas filosóficos, experiência que o levaria a dedicar-se exclusivamente ao rigor não da ciência mas do pensamento filosófico enquanto $a$ ciência. Existem quase tantas filosofias como filósofos e, segundo Husserl, «Aquilo que não for absolutamente justificado, não terá valor». ${ }^{6}$

${ }^{5}$ A tese de doutoramento de Husserl em ciências matemáticas, intitulada Contribuições para o Cálculo das Variações (Halle, 1883), nunca chegou a ser publicada.

${ }^{6}$ Cf. Júlio Fragata, A Fenomenologia de Husserl como Fundamento da Filosofia. Braga: Livraria Cruz / Faculdade de Filosofia de Braga, 1983 (reprodução fotomecânica da edição de 1958), p. 21 (Coleção Filosofia). 
Inventava-se então a busca matemática da filosofia, por assim dizer. Seria naturalmente a lógica que ocuparia o lugar de destaque nas primeiras investigações de Husserl. A lógica, enquanto ciência fundamental (e à boa maneira clássica) dividia-se em três grupos: a lógica das formas possíveis do juízo (gramática), a lógica da não-contradição (a das formas possíveis dos juízos verdadeiros) e a lógica pura ou «Teoria das Ideias» ou «Teoria de todas as teorias possíveis» (Manigfaltigkeitslehre). A lógica, cujo objetivo é o de encontrar as condições de possibilidade da própria ciência engloba-se assim na teoria do conhecimento, precedendo, portanto todas as ciências pelo seu carácter radicalmente esclarecedor das leis e elementos constitutivos do conhecimento. Deste modo radicalizada a lógica é uma filosofia que em si mesma encerra a evidência da sua autojustificação. Parafraseando o filósofo austro-húngaro, enquanto professor ordinário da Universidade de Gotinga, sem uma prévia aclaração dos conceitos mediante um retorno à sua essência na intuição ideatória, torna-se vão qualquer esforço. ${ }^{7}$

Também a influência da psicologia experimental levou Husserl, depois de ter aderido a tal doutrina (em Filosofia da Aritmética por exemplo), a repensar os trabalhos de Lipps, que defendia a lógica enquanto um processo psíquico e uma disciplina psicológica. Tal tese, partilhada inclusive por Wundt, Sigwart e Erdmann na Alemanha, e Mill em Inglaterra, pressuponha uma clarificação filosófica prévia da lógica pela psicologia. No entanto era preciso explicar a passagem das conexões psicológicas do pensamento de um modo geral para a unidade lógica do seu conteúdo, o que já pressuponha não continuidade mas uma flagrante rutura entre as duas disciplinas. Seriam então a ciência matemática e a filosofia, e de resto a própria lógica, compatíveis com um fundamento psicológico? Nasceu assim, da tentativa de ultrapassagem do psicologismo, a partir de 1900, uma das obras mais importantes de toda a história da filosofia, Investigações Lógicas.

Haveria pois que distinguir, em primeiro lugar, ato e conteúdo (do ato), diferenciar portanto leis (lógicas) e juizos, real e ideal. Em segundo lugar, tornava-se urgente esclarecer a confusão entre lei lógica (referente do conteúdo do pensamento) e (conforme à anterior) lei psicológica (reguladora do processo cognoscitivo). Pelo exemplo da máquina de calcular (onde, se desejarmos explicar o funcionamento da máquina, apelamos à eletrónica e não à aritmética), se ilustra o facto de o espírito humano se bem que opere em termos da lei da não-contradição, isso não quer dizer que esta seja a explicação funcional (psicológica) do próprio espírito. Aliás, a importância da constituição psicológica da consciência tornar-se-á irrelevante se considerarmos, acima de

${ }^{7}$ Cf. Husserl, Investigações Lógicas (1900-1901), I, § 67. Ver FHF, Cap. I,2. «O carácter fundamental da lógicas, pp. 23 a 31. 
tudo, a diferença entre juízo (conteúdo ideal do juízo) e ato de julgar (concreto e real). Assim, o juízo é estudado pela lógica enquanto «unidade ideal de significação» (ideale Bedeutungsseinheit), enquanto que o da psicologia é um «ato de consciência» (Bewusstseinserlebnisse). Em conclusão, uma coisa são os pressupostos de uma lei e, outra, os elementos lógicos do seu conteúdo. A lógica tem de ser válida a priori - o número cinco não é o ato de contar cinco: a verdade não pode depender da subjetividade (caso contrário cairíamos no ceticismo psicologista ou relativista das leis empíricas). É fundamental a evidência (apodítica) e não a indução, a verdade e não a probabilidade.

Finalmente, mesmo dentro do domínio da lógica, torna-se ainda imperativo não confundir o carácter absoluto do conteúdo com o modo prático de proceder de acordo com esse conteúdo. A lógica não é apenas uma tecnologia e a lógica pura (ou Teoria das Ideias) pretendida por Husserl menos ainda. Há que encontrar uma filosofia de valor absoluto que nos dê $a$ Verdade - eis uma tarefa possível na história do pensamento humano.

Em que consiste a verdadeira fundamentação? Quais as suas características? Complexa questão a resolver!

Movido pelo angustiado imperativo de fundar uma verdadeira ciência filosófica, o autor do artigo «Filosofia como Ciência Rigorosa» inicia o esforço da fundamentação. Pretende-se agora, segundo Júlio Fragata, encontrar uma "clarificação reflexa» ou racionalização radical da fundamentação da Lógica. ${ }^{8}$ Tal clarificação (Selbstbesinnung) (deve) possui(r) três características:

a) o carácter a priori - a fundamentação radical não pode partir de factos ${ }^{9}$ mas do primordial (tem de ser metempírica); é diferente do axioma geométrico do ego cogito de Descartes, ${ }^{10}$ trata-se de um a priori universal mais exigente, pois é auto justificativo e partirá de «realidades meramente inteligíveis» ou significações puras;

b) o principio da ausência de pressupostos (Prinzip der Voraussetzungslosigkeit) - é a exigência filosófica da aprioridade radical: prescindir de todas as convicções das ciências e «regressar às coisas mesmas», ou seja, à revelação primordial das coisas no espírito ou evidência (e não ao tradicional juízo sobre a existência);

c) a evidência apodítica - não cartesiana mas absoluta, que nos permitirá aceder à pureza insofismável da "coisa» numa atitude filosófica pela qual a realidade aparecerá de modo totalmente reflexivo (evidente) algo a que grande parte das Investigações Lógicas se dedicará.

\footnotetext{
${ }^{8}$ FHF, pp. 45 e ss.

${ }^{9}$ Cf. Investigações Lógicas, I, §§ 67 e 69.

${ }^{10} \mathrm{Cf}$. Meditações Cartesianas, $\S 64$.
} 


\section{§ 2. O problema da evidência e a intuição}

O capítulo II desta obra de Júlio Fragata será preenchido com a exposição do problema da evidência apodítica, intenção significativa e espécies e graus de intuição - um tema pormenorizadamente tratado por Husserl na sexta e última Investigação Lógica (publicada na segunda edição em volume separado).

Em primeiro lugar, impõe-se perceber o duplo carácter da intenção significativa, a saber,

a) pode visar um objeto apenas pela sua significação (intenção vazia ou signitiva)

b) e representá-lo diretamente por meio da sua presença ou preenchimento da intenção numa adequação entre o objeto e o seu conhecimento meramente pensado (intenção intuitiva ou intuição).

Assim, a evidência é precisamente, segundo Husserl, a «vivência da coincidência entre a intenção e o objeto presente» ${ }^{11}$ numa «experiência» essencial, que revestirá diferentes modalidades em conformidade com o caráter do objeto «experimentado».

Teríamos inclusive duas espécies de intuição de objetos:

a) real («em pessoa»; «presentação» (Gegenwärtigung); originária; perceção);

b) imaginada ou recordada (posse indireta do objeto; «a-presentação» ou representação - se bem que o ato de recordar também é originário, já que possui algo da «presentação» - do mesmo modo, e por um fenómeno de «associação binária» (Paarung) ${ }^{12}$ digamos assim, a presentação, porque nunca consegue um preenchimento completo, associa-se sempre a uma apresentação. ${ }^{13}$

Finalmente, e em terceiro lugar, há que distinguir três espécies de objetos:

a) objetos sensíveis: objetos singulares empíricos dados na intuição sensível ou perceção, enfim, o próprio objeto apresentado de modo simples sem necessidade de qualquer fundamento;

b) objetos categoriais: por um lado, o que se afirma de uma coisa ou o estado da coisa (Sachverhalt) ou conteúdo do juízo dado numa

$"$ Cf. Investigações Lógicas, I, § 51 .

${ }^{12}$ Cf. FHF, p.166.

${ }^{13}$ Cf. infra, Apêndice: Organograma I. 
intuição categorial pela evidência de um estado do objeto (intuição dos elementos sensíveis componentes do juízo, e que são fundados portanto na perceção); por outro, qualquer objeto supra sensivel ou ideal ou o aspeto metempírico do objeto sensível (o caso dos objetos sintáticos - pronomes; o plural; o singular; e; ou; não; etc.);

c) objetos universais (ou essências): conceitos universais dados a uma intuição eidética ou ideação que prescinde do facto e é imaginativamente fundada numa singularidade sensivel (as essências materiais não simples mas universais - por exemplo, a cor, o sentimento, uma casa, uma árvore, etc.) ou numa singularidade categorial (as essências formais ou categoriais - por exemplo, objeto, número, ordem, igualdade, etc.).

A intuição é então mais, ou menos, perfeita ou preenchida, dependendo para isso da posse mais, ou menos, plena do objeto admitindo-se assim vários graus (de preenchimento): extensão (a perceção de coisas exteriores que não são captadas na sua totalidade) - v.g. a parte de trás de um objeto que não é vista -, vivacidade (objeto dado de modo confuso) - v.g. maior ou menor luminosidade - e realidade (a intromissão de elementos imaginativos). ${ }^{14}$

O objetivo máximo de Husserl é o da evidência apodítica no seu maior grau de perfeição ou de plena adequação absoluta com a realidade - um ideal kantiano ou caso-limite como horizonte inatingível. Tal evidência implicaria a total ausência de dúvida ou, citando Husserl: «uma evidência apodítica tem o carácter peculiar de não ser apenas a certeza duma evidência das coisas ou dos estados de coisas, mas de se revelar também por meio de uma reflexão crítica, como inteiramente incompatível com a não-existência dessas mesmas coisas».$^{15}$ Percebe-se agora a exigência de um recomeço absoluto ou a radical necessidade do princípio de todos os princípios nas suas Ideias: o que é intuído originariamente é uma fonte de conhecimento e tem de se aceitar tal como se apresenta. ${ }^{16}$ Assuma-se agora a máxima tarefa: um contínuo retorno à evidência.

\section{§ 3. O método fenomenológico ou a inquirição pela realidade originária}

A fenomenologia não é como a literatura, diz Husserl, que se lê em viagem e por distração. ${ }^{17}$ Ela implica uma reflexão racional e uma atitude penetrante atenta à descrição fiel dos fenómenos da consciência (nada nos é

\footnotetext{
${ }^{14}$ FHF, pp. 66 e ss.

${ }^{15}$ FHF, pp. 69-70.

${ }^{16}$ Cf. Ideias I, § 24.

${ }^{17}$ Cf. Ideias I, § 63.
} 
mais íntimo que a consciência, daí a dificuldade e o esforço). Ela é analítica ou descritiva, não prescritiva-dedutiva, e pretende explicar não só os objetos da consciência mas também os próprios atos (inteletivos, volitivos, afetivos, etc.), em suma, os «fenómenos» ou a cogitatio real. E surge-nos, desta feita, toda a trama da fenomenologia transcendental que Júlio Fragata se esforça por clarificar, num desenvolto mas rigoroso estilo expositivo.

O monumental esforço de Husserl foi precisamente tentar tornar inteligível a relação entre o objeto $\mathrm{em}$ si e o objeto imanente $\mathrm{em}$ si mesmo, entre dois mundos por assim dizer, o ser (do mundo) exterior - para o qual estamos naturalmente orientados - e o ser do mundo interior ou do ser imanente - para o qual o filósofo se deve orientar. Eis a velha questão da transcendência portanto, ou seja, tudo o que tem o carácter do em si fora do sujeito (mas não, bem entendido, as objetividades meramente ideais). Alargando-se então o tema da transcendência, teríamos os lugares do transcendente e do transcendental, do ser exterior e do ser interior. Este último, no sentido específico que Husserl the dá, é o próprio conhecimento na sua entidade imanente ou o fenómeno na sua pura aceção, melhor, o ser (ir)real das vivências (mas não fictício). Ora, poderíamos nós perguntar, que interesse poderão ter os objetos transcendentes se eles apenas se dão enquanto transcendentais? Ou doutro modo, se os objetos das sensações apenas têm significado se incluídos na minha consciência ou subjetividade transcendental, qual é então a realidade originária?

Há que tratar seguidamente a questão da epoché ou redução, o instrumento necessário para alcançar essa subjetividade transcendental que Husserl procurou até 1901 (data do último volume das Investigações Lógicas), seguindo-se a chamada crise do seu pensamento (que o próprio filósofo deu notícia no seu diário), ${ }^{18}$ onde se deveria decidir entre dedicar a vida à filosofia ou renunciar ao projeto de encontrar uma «solução segura sobre a essência do conhecimento"), como refere Fragata.

Mas, se o mundo é relativo à minha consciência, terei então de estudar precisamente o modo como ele chega a essa consciência. Assim há que suspender o juízo sobre o mundo, suspender a «posição» ou a «tese» do mundo: «Podemos dizer que vivemos a tese, mas não fazemos uso dela» (Husserl). ${ }^{19}$ É necessário evoluir da atitude natural até à atitude transcendental mediante dois grandes tipos de tarefas: a redução fenomenológica (que nos leva ou nos reduz ao fenómeno) e a redução eidética (que nos leva ou nos reduz à essência).

Por outro lado, para passarmos da crença espontânea na perceção da realidade circundante à adequação plena ou evidente da mesma na consciência

${ }^{18}$ FHF, p. 88.

${ }^{19}$ Ideias, I, § 35 . 
- só a evidência apodítica poderá descansar o filósofo! - encontraremos um caminho mais complexo do que vulgarmente se pensa. Daí ter de se fazer duas reduções mais específicas e sucessivas, a psicológica e a transcendental. A redução psicológica é a epoché no primeiro grau: em lugar de acreditar no mundo em si ou nas sensações (cuja contínua sucessão de «aspetos» ou «perspetivas» (Abschattungen) me leva a concluir que ele existe de facto), descrevo e analiso o mundo como ele me chega à consciência, ou seja, reduzido à vivência (ao mundo psicológico).

Antes de se seguir para um outro nível (o da redução transcendental) deve-se previamente explicar o que é a redução eidética ainda dentro do plano psicológico: posso variar arbitrariamente [pela fantasia por exemplo] sobre fenómenos singulares mas o que se mantém é a essência ou eidos. Por exemplo, do indivíduo («este homem») à essência empírica («homem branco» e desta à essência pura ou à essência no seu carácter absolutamente necessário («o homem como tal») - eis o método das variações. ${ }^{20}$ Foi nas Investigações Lógicas II (logo na Introdução) que Husserl considerou esta primeira fase do seu radicalismo, apresentando a fenomenologia (embora a apelidasse já de «pura») ainda como ciência descritiva das essências. No entanto com a próxima redução o assunto mudará de figura.

E segue-se algo que permitirá finalmente inibir todo o interesse existencial ou do ser (Seinsinteresse), a redução transcendental. Pouco importa neste caso a mundaneidade, pois a tarefa é transformar a subjetividade psicológica na subjetividade transcendental, para atingir o plano das evidências apodíticas. E isto num passo fundamental: o meu eu psicofísico (a existência de mim mesmo que reflito e os seus atos) deve ser posto «entre parênteses», já que toda a «posição de natureza» tem de permanecer fora de circuito. Para quê? Para atingir o eu absoluto ou o eu transcendental fenomenológico (para alcançar a possibilidade de ter uma experiência genuinamente filosófica), a saber, o campo da autoexperiência transcendental fenomenológica (das Meditações Cartesianas). ${ }^{21}$ Este tipo de eu torna-se deste modo concebível na sua relação ao objeto intencional desprovido, neste caso, de qualquer caráter psicológico e tomado unicamente enquanto idealidade meramente significada, enquanto sentido portanto. Ponho o mundo fora de circuito mas retenho-lhe o sentido. Eis a explicitação plena do eu penso o pensado, do ego cogito cogitatum. Trata-se, por conseguinte, de um eu depurado do mundo, transformando-se num «espectador desinteressado» (uninteressierter Zuschauer), ou seja, o filósofo. É o eu da atitude fenomenológica ou transcendental: aprioridade absoluta numa ausência radical de pressupostos e evidência imediata. 
O que é (agora) a fenomenologia? A fenomenologia, neste plano de tão importantes reduções seguido até aqui, é segundo Husserl, uma «Disciplina puramente descritiva que explora, pela intuição pura, o campo da consciência transcendentalmente pura»s. ${ }^{22} \mathrm{Em}$ vez do mundo temos a consciência 'do mundo'!

\section{§4. O mundo da consciência pura enquanto fluxo vivencial de fenó- menos. A polarização Noesis/Noema da intencionalidade e o objeto intencional}

A constituição transcendental (o modo como o objeto nasce na consciência pura) deste novo mundo, limita-se ao campo das experiências intelectuais evidentes e apodíticas, mediante a conjugação fundamental sujeitoobjeto. Tal inovadora dimensão teria de ser estudada, num primeiro momento, através de uma análise de fenomenologia estática, quer dizer, uma descrição da unificação temporal do fluxo da consciência enquanto série de vivências e depois, num segundo momento, através de uma fenomenologia dinâmica, quer dizer, uma explicação genética do seu carácter apoditicamente evidente. ${ }^{23}$ Iniciaremos então o estudo da unificação do fluxo consciente.

Júlio Fragata cita-nos uma singular frase de Husserl que explica que esse campo dos fenómenos puros é, mais precisamente, um fluxo heraclitiano de fenómenos, ou se quisermos, é um contínuo (leia-se perene) indefinido de durações (atualidades e inatualidades) ou momentos temporais incomensuráveis, parafraseando Husserl, não medíveis nem pelo relógio nem pela posição do sol. Eis o tempo imanente ou puramente vivido, algo a que o filósofo começou a dedicar-se depois da publicação das suas Investigações Lógicas. Esta temporalidade é uma «forma necessária que une as vivências às vivências». ${ }^{24} \mathrm{~A}$ consciência no seu fluxo é o "agora vivido» que condensa o passado e o futuro, a retenção e a protensão. No que respeita a estas últimas, não se trata nem de uma reprodução nem de uma antecipação memorativas, mas a inerente implicação do passado e do futuro no presente cujo elemento unificador é o eu puro, isto é, o sujeito idêntico no «agora» contínuo, o que se mantém (misteriosamente...) sempre o mesmo em todas as mudanças reais e possiveis do fluxo vivencial, enfim, a chamada transcendência na imanência. Dizia Husserl em conferência na Sorbona em fevereiro de 1929: «A vida, no

\footnotetext{
22 Cf. Ideias I, $\$ 59$ e $\$ 75$.

${ }^{23}$ Cf. FHF, p. 120.

${ }^{24}$ Cf. Ideias I, § 81 .
} 
seu flutuar, no seu fluxo heraclitiano, é uma síntese unitiva» e mediante esta última «toda a vida consciente é penetrada pela relação ao objeto». ${ }^{25}$

Percebe-se então que é através do tempo que a vivência se desenvolve (sendo que a própria unificação temporal não é por si mesma consciente). Não obstante, como é que a consciência se mantém una, ou de outro modo, o que é que unifica os elementos constitutivos da estrutura designativa dos objetos? A resposta é relativamente simples: é a intencionalidade que permite considerar o fluxo da vivência e a unidade da consciência. Nem a síntese temporal existiria sem a unificação consciente operada pela intencionalidade, ou seja, em termos husserlianos das Ideias, por essa «peculiaridade em virtude da qual as vivências são consciência de alguma coisa» ${ }^{26}$ ou de implicar como cogito o seu cogitatum portanto (e neste caso ao estilo das Meditações Cartesianas). De modo bem diferente do seu mestre Brentano, que a considerava enquanto psicologicamente dependente de um objeto mundano, Husserl vê a intencionalidade como pertencente ao campo da imanência pura onde os atos não possuem algum tom psicológico e nem os «dados sensíveis» serão intencionais.

De uma vez por todas, a intencionalidade é uma «atividade» (Leistung) que não parte do ato mas do eu puro em direção ao objeto e que encontrou um substrato intrínseco à vivência, a saber, o. conjunto dos dados hiléticos ou sensíveis (Empfindungsdaten) - e que haverão de constituir a explicação da diversidade dos objetos de que o sujeito tem consciência. Os dados hiléticos são, por exemplo, os dados da cor, tato, som, etc. Tais elementos materiais por si só nada designam, pois são desprovidos de intencionalidade - «não ouço impressões de sons mas a canção da cantora», explica Husserl. Mas sem a intencionalidade (que in-forma) esses dados (ou «momentos sensíveis» segundo Husserl) ${ }^{27}$ não poderiam ser significados (vivificados). É a intencionalidade que permite ao sujeito adquirir o «sentido do objeto» e pela qual a consciência se torna verdadeiramente cognoscente. A intencionalidade informante é a noesis, «[...] nome também aplicado para designar o conjunto total da vivência orientada subjetivamente, que inclui os próprios dados materiais enquanto informados», explica Fragata. ${ }^{28}$ Por conseguinte, os dados hiléticos assignificativos transformam-se (pela atividade polarizadora da intencionalidade) em dados noemáticos ou noemas significados numa vivência orientada objetivamente. Finalmente, nesta vivência distinguiremos,

\footnotetext{
${ }^{25}$ Cf. Husserl, Conferências Parisienses.

${ }^{26}$ Cf. Ideias I, § 84.

${ }^{27}$ Cf. Ideias I, § 85.

${ }^{28}$ FHF, p. 133.
} 
de acordo com Husserl, «componentes reais (reellen) das vivências intencionais e os seus correlatos intencionais». ${ }^{29}$

Em suma, a noesis é a parte «real» ou intrínseca da vivência (com os seus «elementos materiais» acima descritos) e o noema é o conjunto desses dados enquanto «projetados» pela vivência (não pertencendo portanto aos seus constituintes «reais») e, porque «tende» para o «objeto» que designa, é o componente «irreal» ou «intencional» da vivência. Com a teoria do noema (graças ao qual, escreve o nosso autor, o «objeto adquire uma presença imanente diversa, ao mesmo tempo, da consciência que se tem dele»), ${ }^{30}$ se abre todo o campo do «fenómeno» típico da fenomenologia transcendental. ${ }^{31}$

Como se chega então ao objeto intencional? Para responder a esta questão o professor Júlio Fragata começa por alertar para a necessidade de se compreender bem a estrutura do noema. E para seguir um exemplo do próprio Husserl, podemos afirmar que o conhecimento de uma árvore é um noema completo ou o conjunto de elementos que o constituem e afetam os modos como se tem consciência da árvore: a árvore pode ser percecionada, recordada, imaginada, vista numa fotografia, ser concebida em diferentes modalidades de existência real: certa, duvidosa, provável, etc. - são os caracteres noemáticos (que envolvem o «sentido íntimo do noema») ${ }^{32}$ ou o que Husserl chamou «caracteres de ser» (Seinscharaktere).$^{33}$ Estes últimos equivalem aos caracteres noéticos da crença (ou dóxicos) que explicam o carácter da posição transcendente do objeto na consciência transcendental e pertencem aos caracteres téticos (ou formas posicionais).

Três conclusões então:

a) os caracteres noemáticos podem variar permanecendo idênticos os dados sensíveis ou o mesmo objeto;

b) os dados sensiveis ou materiais (aspereza, dureza, cor, etc.) são diferentes dos caracteres noemáticos (existência real ou duvidosa, perceção, imagem, etc.);

c) os dados sensíveis (que podem manter-se idênticos através dos diversos caracteres noemáticos) são como que projetados no noema devido à intencionalidade, determinando, assim, o objeto ou núcleo noemático (ou sentido objetivo).

${ }^{29}$ Cf. Ideias $\mathrm{I}, \S 88$.

${ }^{30}$ FHF, p.135.

${ }^{31}$ Cf. infra, Apêndice: Organograma II.

${ }^{32}$ Cf. FHF, p.137.

${ }^{33}$ Sobretudo a partir do $\$ 103$ de Ideias I. 
Por seu lado, este sentido objetivo é precisamente o como das determinações do objeto e é mais vasto do que a própria significação lógica. Este sentido constitui-se pelo conjunto dos predicados ou determinações que variam segundo as perspetivas (Abschattungen) do objeto, enquanto este permanece sempre o mesmo (como síntese de todas as variações), mas apresentado com outros predicados (ou outros elementos determinantes). O sentido não é pois uma essência concreta mas abstrata, quer dizer, a consciência da essência e não a essência. Escreve Fragata: «Portanto, assim como, através das variações dos caracteres noemáticos, transparece um sentido idêntico designativo do objeto, assim também, através das variações dos predicados constitutivos deste sentido, se destaca um significado, um cogitatum idêntico que, distinguindo-se do "núcleo noemático", ocupa um ponto particularmente íntimo do noema e forma como que o centro do núcleo». ${ }^{34}$ Trata-se, de acordo com Husserl, do «objeto simplesmente considerado» ou objeto intencional. O objeto intencional, ponto invariável e central, é o «objeto-pólo», o «X determinável» mas «invariável», é o «puro X por abstração de todos os seus predicados». ${ }^{35}$

Em jeito conclusivo: «Portanto, assim como a vivência tem um conteúdo intrínseco, que é a nóesis, e se refere a um correlato intencional, que é o noema, também o noema possui um conteúdo intrínseco, que é o sentido, e refere-se ao seu correlato, que é o significado ou "objeto intencional"». ${ }^{36}$

\section{§5. A constituição do objeto em geral e a constituição do outro através do corpo. A constituição intersubjetiva ou o problema da objeti- vidade}

Vimos já que a consciência transcendental do objeto (enquanto efetivação intencional do eu) apenas se constitui numa síntese temporal no ego cogito cogitatum: o objeto torna-se intrinsecamente consciente enquanto pensado (cogitatum). É evidente pois que não é possível conceber algum objeto sem ser pensado, o que exige uma consciência doadora de sentido num campo de objetividades que resultam, pela intencionalidade, da função posicional do eu, quer dizer, qualquer objeto na nossa mente possui sempre o caráter de uma experiência: uma intuição nos seus diversos graus de preenchimento, ou mesmo uma perceção. No caso da intuição ela é sempre doadora porque dá o sentido constituindo assim o objeto. No entanto tal constituição implica também a evidência apodítica ou a posse insofismável do objeto no meu espírito.

\footnotetext{
${ }^{34}$ FHF, p. 141.

${ }^{35}$ FHF, pp. 142 e ss. Cf. infra, Apêndice: Organograma III e IV.

${ }^{36}$ FHF, p. 143.
} 
Permanece, não obstante, um problema: como ultrapassar os limites da individualidade da (minha) consciência transcendental para se poder adquirir um caráter plenamente objetivo? Com efeito, na experiência da vida da minha consciência descubro não só a vida dos outros (ou uma pluralidade de sujeitos), já que o(s) outro(s) eu(s) se constitui(em) pela sua semelhança ao meu próprio eu, mas também que o meu próprio eu se constitui como oposto ao objeto - o pertinente e inexaurível tema filosófico que ocupa a última Meditação Cartesiana e que permitirá a ultrapassagem do solipsismo fenomenológico.

Trata-se agora da constituição do outro ou do problema mais geral da alteridade eu-objeto, essa «maravilhosa polaridade» como referiu Husserl: ${ }^{37}$ ao constituir-se o objeto constitui-se o eu. Esquematicamente, e em termos husserlianos, explica o Professor Fragata que do eu saem (intencionalmente) dois raios: um «ponto de divergência» em relação ao objeto e um «ponto de convergência» sobre o objeto projetado no eu, produzindo-se deste modo a consciência do objeto enquanto inseparável da consciência do eu, isto é, o «ego monádico concreto» que não prescinde da polaridade sob pena de não poder existir consciência. Por conseguinte, é este «fluxo multiforme» dos objetos constantemente significados na minha consciência que me permite a mim próprio auto constituir-me como um eu sempre presente, ou sempre o mesmo, nessa história.

Contudo, no meio dessa imprescindível alteridade para a constituição do eu monádico está o corpo (Leib) orgânico que é apreendido enquanto objeto e, simultaneamente, enquanto integrando ele mesmo o próprio eu. O meu corpo, que se me opõe, é o «aqui» constante ou o «ponto zero» (Nullpunkt) em relação ao qual se localizam todas as outras coisas, ou o «ponto de intercâmbio» (Umschlagspunkt) entre o mundo exterior e o sujeito que conhece ou ainda, como escreveu Husserl, «o homem concebe-se, como uma 'significação', através do corpo». ${ }^{38}$

Mais ainda, o outro constitui-se precisamente pelo carácter intermediário do (meu) corpo. Alter é o alter-ego. O ego (o eu pessoal ou unidade psicofísica que sinto «com poder imediato sobre o meu corpo» e que age no mundo) é-me precisamente revelado pela apreensão de outros corpos diferentes do meu. Nesse confronto concebo um corpo exterior que é o meu e verifico a existência do outro que, refere Júlio Moreira Fragata, «equivale à constituição do outro eu». ${ }^{39}$ Essa inclusão do mundo em mim explica-se pela «teoria da experiência do outro» (Husserl) ou pelo conceito de intropatia (Einfühlung), equivalente a

\footnotetext{
${ }^{37}$ Cf. Ideias II, $\$ 25$.

${ }^{38}$ Cf. Ideias II, $\S 56$. Ver também $\S \S 41$ e 42.

${ }^{39}$ FHF, pp. 163 e ss.
} 
uma «intro-significação» (Eindeutung), ${ }^{40}$ a saber, o mundo adquire um sentido quando compreendido na e pela consciência: sinto o outro em mim do mesmo modo que pelo meu corpo me sinto a mim mesmo: constituo o outro à minha semelhança. E como o outro não é apenas um momento daquilo que me é próprio, ele também não poderá ser identificado com a consciência que dele tenho, num solipsismo enganador.

E eis que nos surge outra delicada situação a resolver: dos outros, das outras pessoas que gozam dos mesmos privilégios que eu já que ambos somos sujeitos transcendentais, não existe intuição doadora originária, elas não são meramente representados mas são, de facto, outros transcendentes. Ora, sem renunciar à epoché (já que ela torna os outros tão-só em significados na minha consciência), como compreender então que eles existem de facto por si? A resposta está na teoria da «constituição intersubjetiva» ou se quisermos dizê-lo de um modo mais geral, no problema da objetividade ou na universalidade do juízo para todos os sujeitos do conhecimento.

Já sabemos que na constituição subjetiva o objeto é idêntico pela multiplicidade de noemas ou aparências individuais. Enquanto isso, na constituição intersubjetiva a verdadeira coisa é o objeto idêntico pela multiplicidade de noemas duma pluralidade de sujeitos. Existe pois a real necessidade de um acordo numa comunidade de sujeitos: (diríamos com Júlio Fragata) a hipótese da nadização levou Husserl à epoché e a hipótese das alucinações leva-o agora à intersubjetividade. Como reconhecer então o objeto numa comunidade? A resposta é simples: pela intropatia. Experimentar os outros como não-eus, eis o caminho para conseguir alcançar a objetividade, ou seja, (esclarece Husserl logo no primeiro parágrafo de Ideias III) uma «compreensão mútua entre uma pluralidade de eus que experimentam», e o mesmo é dizer, o grau do «nós transcendental» (como o último sujeito fenomenológico que apreende a realidade sem erro) ou o mundo válido para todos - mas «não um espírito super-individual, escreve Fragata, que pairasse como distinto acima do espírito individual». ${ }^{41} \mathrm{~A}$ partir daqui se construirá uma Filosofia objetiva com a qualidade de uma Philosophia perennis.

\section{§ 6. O que é a realidade? O idealismo husserliano e o caráter metódico da fenomenologia/filosofia}

Para se encontrar um fundamento da filosofia na fenomenologia de Husserl é necessário levar a investigação até mais longe, e perceber qual a posição do filósofo perante a questão da realidade. Se bem que exista uma crítica clara

\footnotetext{
${ }^{40}$ Sobre estes conceitos ver principalmente Ideias II, § 51 e Meditações Cartesianas, $\S 51$.

${ }^{41}$ FHF, p.177.
} 
à atitude natural, ${ }^{42}$ a realidade por ela captada não é vista de modo idealista - se bem que tenha reaberto, segundo alguns autores, toda a questão metafísica. ${ }^{43}$ Mas, em boa verdade, o idealismo surge apenas no plano da atitude fenomenológica ou transcendental: idealismo transcendental fenomenológico. Tal posição husserliana possui, no ponto de vista de Júlio Moreira Fragata, três características fundamentais, pela negativa, e mais uma pela positiva, a saber,

a) não nega a verdadeira existência do mundo real; não é um esse est percipi, já que o esse é a realidade posta entre parêntesis (a do objeto transcendental portanto) e o percipi não engloba o esse como elemento real (real), mas apenas como o real (reell) da vivência;

b) não supõe a atividade de um sujeito supra individual do tipo hegeliano mas apela, pelo contrário, à intersubjetividade;

c) não se refere a um produto de uma criação subjetiva de um sujeito individual - caso contrário a epoché seria dispensável, e é precisamente ela que possibilita o idealismo sem contradizer o realismo;

d) (e pela positiva) é uma atitude metódica, um modo (não cartesiano) de proceder em relação a um fim e que obriga (não o homem mas) o fenomenólogo à redução (assim como o geómetra que prescinde da questão da existência ou não existência dos casos particulares).

Por conseguinte, o objeto é imanente (conceito) porque (dotado de) intencional(idade), o que forçosamente o remete para o objeto exterior, consequentemente, para as coisas. Ele não se encontra encerrado nem na pura significação nem na simples aparência - é a ultrapassagem da velha dicotomia idealismo/realismo. A «constituição» do objeto salienta, tão-só, a impossibili-

42 Cf. supra, $\S 3$.

${ }^{43}$ Veja-se por exemplo Poeggeler: «A verdadeira tragédia de Husserl não residiria então na injustiça que lhe impuseram por razões políticas, nem mesmo no facto de os discípulos, tanto precoces como tardios, que ele secundou na abertura para uma liberdade nova de pensamento, não terem seguido o caminho do seu pensamento. A profunda tragédia de Husserl estaria, pois, no facto de ele, que se pronunciou pelas próprias coisas e contra todas as construções metafisicas, ter reconstruído, em última análise, o caminho dos sistemas metafísicos modernos sem mesmo se aperceber disso e sem que tenha descoberto os pressupostos que poderiam existir». O. Poeggeler, La pensée de Martin Heidegger, trad. par Simom. Paris: Aubier-Montaigne, «Présence et pensée», 1967 (citado por Resweber, Jean-Paul, O Pensamento de Martin Heidegger. Coimbra: Almedina, 1979, p. 66). Ou ainda Piaget: «Para Husserl, ela [a questão fundamental] é pelo contrário [em relação a Kant] a de atingir "a origem do mundo" pois que as "formas" são ao mesmo tempo essências determinantes. Daqui resulta que a sua epistemologia é solidária de um idealismo, não subjetivo (ou psicológico), mas transcendental e ao mesmo tempo de uma ontologia metafisica que não se quer separada das ciências mas pretende encontrar de novo a união indissociável da forma e da essência em todo o ato do conhecimento, seja ele qual for». Cf. Lógica e Conhecimento Científico (primeira edição francesa em 1967), um monumental conjunto de estudos epistemológicos sob a sua direção (Porto: Livraria Civilização, 1980), 1. o volume, pp. 41-42. 
dade do conhecimento sem a formação do objeto significado na consciência, ou seja, o resultado ideal do complexo noético-noemático. Não se trata de um idealismo puro mas de uma idealização, melhor, diz o autor, o idealismo de Husserl é irreal-metódico. ${ }^{44}$

O método - eis precisamente aquilo que de maior importância surgiu a partir das descobertas de Husserl. Apesar da tradicional dificuldade da definição da própria filosofia, Husserl possuiu uma conceção clara do que ela é, ou seja, uma «ciência ou um conjunto de ciências», melhor, todas as disciplinas que se dedicarem às questões de carácter mais fundamental são ciências rigorosas. Trata-se pois de uma fundamentação última ou uma universalis sapientia que dirige o conhecimento (ou a razão) à compreensão das suas possibilidades. Neste sentido, seria uma metafísica formada em sistema de disciplinas mas não fundada no axioma do ego cogito. O que é genuinamente filosófico é o radicalmente reflexo desenvolvido na atitude racional da epoché. A fenomenologia é a «ciência dos começos» uma espécie de «arqueologia» como dizia Husserl, ${ }^{45}$ ou a filosofia primeira enquanto fenomenologia transcendental identificada com a metafísica de um modo geral (pelo menos a partir de 1913 com a publicação do primeiro volume das Ideias). Mas, anunciada já no curso de Friburgo (1023-24), a filosofia torna-se mais especificamente um «autodesenvolvimento sistemático da subjetividade transcendental», a saber, uma filosofia transcendental que possa resolver problemas igualmente transcendentais do mundo objetivo - aquele que a sua Krisis pensará. Graças ao aspeto metódico da fenomenologia, a filosofia poderá entrar em todos os campos da ciência.

E o carácter metódico da fenomenologia possui duas características:

a) o método de evidenciação - mais específico e original, pretende fundar uma evidência absoluta; é a fenomenologia enquanto ciência e filosofia primeira pela Selbstbesinnung (auto reflexão) radical e universal, sob a forma da redução transcendental pela descrição sistemática do conteúdo lógico de uma eidética intuitiva, para observar as «coisas» como se manifestam na sua pureza original;

b) o método descritivo - complemento necessário do método de evidenciação; não é por natureza dedutivo mas também não é antidedutivo: serve-se do carácter mediato da dedução (como de qualquer outro processo não-intuitivo), apenas na medida em que ela ajuda a chegar às coisas, sendo estas, por sua vez, objeto de uma ulterior intuição direta da essência que lhes conferirá o caráter do dado. 
A descrição, corre, com efeito, o perigo de se limitar ao dado do mundo sensivel. Para ultrapassar este problema é necessário socorrermo-nos de uma «conceção analógica do ser como que inata ou estrutural à mesma consciência», explica Fragata. ${ }^{46}$ Esclareça-se, por outro lado, que em Husserl a própria intuição categorial pertence ao domínio material das objetividades. Daí a sua simpatia por David Hume e, em suma, o carácter empirista da sua fenomenologia.

\section{Parte II}

\section{Algumas considerações sobre a conceção fragatiana da femonenologia de Edmund Husserl}

\section{§1. Introdução}

Após termos dado notícia de tão importante receção fragatiana do pensamento de Husserl, desejamos agora tentar apresentar, e criticar, a leitura mais pessoal que o autor fez desta mesma fenomenologia. Para isso partiremos do oitavo e último capítulo de $A$ Fenomenologia de Husserl como fundamento da Filosofia, onde o autor apresenta a sua «Conclusão crítica», e de alguns outros escritos mais dispersos do mesmo. Em boa verdade, depois de mais de duas centenas de páginas onde esporadicamente mas não de modo casual, o nosso teólogo-filósofo apresenta algumas teses escolásticas como possíveis interpretações mais corretas da fenomenologia husserliana, opta-se finalmente por uma mais declarada e prosélita visão do problema filosófico do fundamento primeiro de todas as coisas. Apresentaremos assim, em primeiro lugar, e de modo já por nós problematizado, essas teses por assim dizer menos visíveis ao longo do texto, e daremos conta do essencial da referida «Conclusão crítica». Finalmente, encetaremos um (forçosamente incompleto) ensaio de fenomenologia crítica aplicada ao pensamento do nosso autor.

\section{§ 2. A «Conclusão Crítica» de $A$ Fenomenologia de Husserl como funda- mento da Filosofia}

Na «Conclusão Crítica» de FHF, Júlio Moreira Fragata trata o problema da possibilidade de uma filosofia como ciência rigorosa, concluindo, com Husserl, que a cientificidade da filosofia é diferente da cientificidade das ciências empíricas, tentando, igualmente, refutar o historicismo. De resto, Husserl, fas- 
cinado pela sistematização, e pretendendo uma ciência plenamente racional, ensaiou o alcance das «evidências apodíticas» e teve de refugiar-se na atitude transcendental. O filósofo desejou, enfim, encontrar um domínio puramente racional onde a razão procedesse analogicamente e de modo metempírico e, igualmente, segundo razões também metempíricas das coisas. «Infelizmente, escreve Fragata, a dúvida mantém-se por vezes mesmo em relação ao carácter suficiente da evidência». E será, pois, «neste momento que a fé pode influir na filosofia, embora indiretamente, indicando onde está a verdade, e portanto orientando o pensamento filosófico ${ }^{47}$ Ora, em boa verdade, sendo a evidência a necessária ciência da intuição, requer-se uma «intuição originária», uma base do conhecimento cuja perfeição dependerá da plenitude da posse do objeto. O grau de evidência é, pois, determinado pela natureza do objeto, o que irá provocar um «empirismo exagerado» em Husserl e que vai intrometer-se no seu racionalismo, mas que o obriga a tomar consciência de que «pelo menos como sujeito empírico, não pode ter uma perceção que apreenda intuitivamente o mundo na sua totalidade» - como afirma Husserl no $\S 50$ da sua primeira Investigação Lógica ${ }^{48}$ - levantando assim a hipótese de um sujeito metempírico proprietário de uma intuição perfeita na sua subjetividade. Quer dizer, Husserl «encerrou-se demasiado no carácter especificamente humano da "intuição"»." ${ }^{49}$

O mesmo se passaria a um nível mais elevado, o do sujeito transcendental que, em última instância, nos conduz à complexa questão do terceiro «eu», anunciado já por Fink no conjunto dos célebres estudos aprovados por Husserl («Studien zur Phanemonologie» - 1930-1939). Com efeito, quando é que se pode ter consciência evidente de que se praticou a epoché transcendental, senão a partir do momento em que se exige um «absoluto» mais radical como fundamento do (eu) «absoluto transcendental» e assim indefinidamente? Mesmo a intersubjetividade transcendental, ou sujeito transcendental intersubjetivo, embora seja designado «absoluto», «não se apresenta com evidência num plano que ultrapasse» os limites da verificação para qualquer ser especificamente humano. «Deste modo, conclui Fragata, a garantia fenomenológica da objetividade pela intersubjetividade transcendental participa da inconsistência do estabelecimento do objeto transcendental..> ${ }^{50}$ Por conseguinte, aquele tipo de apriorismo (que resulta da não-consideração da absurdidade do que se afirma) que Husserl apontava ao empirismo, poderá 
ser agora dirigido à sua atitude transcendental que, pelo menos, está longe de possuir a clarividência que o filósofo alemão lhe pretendeu atribuir.

Em boa verdade, o fundamento de todas as provas que resulta de juízos imediatamente válidos pela intuição doadora originária, não é, ao contrário do que seria de supor, alcançado ao estabelecer-se a fenomenologia husserliana, reduzindo-se a tão almejada fundamentação rigorosa a um fracasso de inspiração neo-cartesiana! O sonho da unificação da Filosofia mantém-se! E apesar de Husserl ceder ao idealismo, melhor, de «contaminar o seu pensamento com o idealismo fenomenológico», como bem sublinhou N. Hartmann, que conduziu Max Scheler ou o próprio M. Heidegger a abandonaram a atitude transcendental, conseguiu, pelo menos, desviar os filósofos do idealismo iniciado por Kant e ajudar a franquear as portas ao realismo: a realidade é conhecida espontaneamente. Nesse meio termo, para Júlio Fragata, o verdadeiro fundamento da filosofia é, ainda, a fenomenologia: «a observação direta do que se manifesta à consciência» pela evidência das coisas. ${ }^{51}$

Por isso, a filosofia tem de começar pelo «ver espontâneo», logo «libertado de todos os preconceitos», deixando de lado a atitude transcendental e aceitando o plano natural.

\section{§ 3. Outras teses fragatianas em A Fenomenologia de Husserl como fun- damento da Filosofia}

Ao longo desta obra, Júlio Moreira Fragata vai publicitando, de quando em vez, as suas críticas mais ou menos veladas ao pensamento do mestre Husserl e, ao mesmo tempo, apresentando de modo mais explícito uma interpretação que o aproxima de Tomás de Aquino.

Partindo do pressuposto que criticar a fenomenologia de Husserl é criticar igualmente a sua filosofia, ${ }^{52}$ o professor salienta o facto da insuficiência ou uma mais plena completude do próprio fundamento husserliano da filosofia. Com efeito, se «O conhecimento científico é, como tal, um conhecimento a partir do fundamento», ${ }^{53}$ então esse fundamento apresenta-se, em Husserl, «quase à maneira dum limite inatingível» ${ }^{54}$ e é o problema da verdade que se torna agora visível. Husserl suporia a doutrina das verdades em si, influenciado pelo austríaco sacerdote-filósofo Bernardo Bolzano (que o teria

${ }^{51} C f$. FHF, p.260.

${ }^{52} C f$. FHF, p.222.

${ }^{53}$ Investigações Lógicas, I, § 63.

${ }^{54}$ FHF, p. 27. 
influenciado na sua conceção da lógica) ${ }_{,}^{55}$ ou seja, a verdade não dependeria da constituição psicológica da consciência mas possuiria um carácter absoluto ou válido para si mesma.

Quer-nos no entanto parecer que esse percursor de Brentano e de Husserl (no seu igual esforço para libertar a lógica da psicologia e fazê-la depender apenas do significado dos termos da proposição), e do qual o próprio Husserl (apesar de o elogiar como brilhante matemático e lógico) nunca se considerou discípulo, estaria mais preocupado com uma exploração místico-metafísica das supostamente ideias verdadeiras ou objetivas independentemente de serem ou não conhecidas por um sujeito (humano), do que com uma teoria do conhecimento baseado no complexo noético-noemático que, como sabemos era, no fundo, a grande preocupação do mesmo Husserl.

Por outro lado (e é interessante este exemplo!), quando o autor refere esta influência cita uma passagem (algo descontextualizada) dos Prolegómenos à Lógica Pura: «pois a frase 'não existe nenhuma verdade' tem um sentido idêntico ao da frase: 'existe a verdade de que não existe nenhuma verdade'», ${ }^{56}$ para logo mostrar em rodapé o seguinte argumento (algo circular...) de Tomás de Aquino (no início da Suma Teológica): «Quem nega a existência da verdade, concede que a verdade não existe, pois se a verdade não existe, é verdade que a verdade não existe», facilmente concluindo «a aproximação do pensamento de Husserl com o de S. Tomás». Mas, em rigor, no contexto dessa citação, Husserl critica o relativismo específico e, em particular, o antropologismo, tentando para isso diferenciar os vários contrassensos bastas vezes provocados pela indistinção entre juizo verdadeiro e o seu conteúdo. E no caso do grande filósofo aristotélico que foi S. Tomás, é Deus, cujo pensamento se encontra perfeitamente conforme ao seu ser, enquanto veritas in re e simultaneamente veritas in intellectu, que garante a ligação das coisas com a verdade lógica que se pode ter das mesmas ou do juízo com o objeto a que diz respeito - o que, convenhamos, difere da presunção husserliana do objeto intencional.

Pretende-se colocar o grande comentador de Aristóteles e o pai da fenomenologia no mesmo plano, equipará-los em termos da teoria de conhecimento, especialmente quando se afirma que a mera intenção deste último está para os elementos intelectuais do primeiro, assim como a coisa presente de Husserl está para os elementos sensitivos de Aquino, isto para tentar interpretar o tipo de síntese que a intenção produz entre a mente e o objeto ${ }^{57}$ Entre-

${ }^{55}$ FHF, p. 37.

${ }^{56}$ Prolegómenos à Lógica Pura, § 36.3. (o primeiro volume das Investigações Lógicas de Husserl). Veja-se a tradução portuguesa de Diogo Ferrer. Lisboa: Phainomenon-Clássicos de Fenomenologia / Centro de Filosofia da Universidade de Lisboa, 2005. p. 135

${ }^{57}$ FHF, p. 55, particularmente NR 6. 
tanto, faça-se justiça, o autor referirá mais à frente que a intuição sensível dos objetos em Husserl (que é derivada do modo do objeto) é diferente da intuição sensível dos escolásticos (faculdade apreensiva), que a opõem à intelectual..$^{58}$ Tratam-se de «exigências insaciavelmente radicais»» ${ }^{59}$ que caracterizam a fenomenologia - o que, de algum modo, sugere que Fragata pressupõe já a busca do fundamento em Husserl como dificilmente conseguida de modo pleno: são essas «alturas» típicas do voo husserliano que o levarão às muitas dificuldades encontradas no caminho.

Também St. Agostinho é chamado para fazer prevalecer a filosofia medieval sobre a contemporânea. É no livro XI das Confissões («O Homem e o Tempo») que este pensador admite que apenas ao homem é permitido pensar o tempo (do passado, do próprio presente e do futuro) e medir apenas o tempo que agora decorre, percecionando assim apenas o que se sucede e não o que sucedeu anteriormente para o poder captar agora. É verdade que, como referiu Le Blond, Agostinho terá marcado de modo definitivo a importância do carácter psicológico do tempo enquanto pertença da consciência. ${ }^{60}$ Trata-se, de modo outro, no nosso ponto de vista, mais da velha questão primeira de Deus creator omnium de Santo Ambrósio, do que a do continuum temporal da consciência, aquele que acompanha e justifica a permanência do cogito em todas as nossas aceções possíveis.

Outra equivalência é encontrada pelo autor: entre noesis/pensamento do objeto (pela escolástica) e noema/objeto enquanto pensado (pela escolástica) ou, tão-só, a ideia considerada de modo subjetivo (o ato em Husserl) e de modo objetivo (o conteúdo em Husserl) tratando-se, pois, de uma distinção da razão e não de uma distinção no ou do real. ${ }^{61}$ Digamos que, nesta fase do nosso estudo, não desejamos descurar as distinções husserlianas entre real e reell, nem tão pouco, a sua explicação do conteúdo intencional enquanto objeto intencional do ato, assim como da significativa coincidência entre objetos intencionais (simplesmente imanentes) e objetos reais (verdadeiros e transcendentes) e da sua «absurda» distinção, tanto por questões de ordem conceptual como ontológica - de modo a evitar «erros que se perpetuam através dos séculos» e sonhados, por exemplo, no argumento ontológico de Santo Anselmo! ${ }^{62}$

\footnotetext{
${ }^{58}$ FHF, p. 60.

${ }^{59}$ FHF, p. 70.

${ }^{60}$ Veja-se a este propósito o estudo de J. M. Le Blond, SJ, Les Confessions de Saint Augustin. Paris: 1950, p.256.

${ }^{61}$ FHF, p. 135.

${ }^{62}$ Sobre este último caso ver a V.a Investigação, Apêndice aos $\S \S 11$ e 20,2.
} 


\section{§4. Conclusão}

Quer-nos parecer que o problema principal que subjaz, de modo mais ou menos explícito, na escrita de Júlio Moreira Fragata é, de alguma forma, o mesmo que o de Husserl, ou a clássica questão da assunção da verdade como forma lógica anistórica.

No caso de Husserl, e mesmo na sua Krisis, pensamos que não chegou a relacionar a história com a fenomenologia. Daí toda a sua incompleta, entrecortada e inconsequente polémica com Dilthey, já que, contrariamente a este último, admitia claramente a natureza aistórica da validade das formas lógicas. A dicotomia entre a filosofia husserliana als reine Wissenschaft das formas lógicas e a filosofia diltheyneana das criações espirituais como Weltanschaaung, afigura-se-nos como uma reedição temática da necessidade pragmática e científica de uma impossível objetividade entendida enquanto verdade única e universal.

A demanda do pressuposto absoluto, do critério de demarcação entre verdade e não-verdade, o que sempre obrigou os filósofos a estabelecerem um método para a filosofia, é o real motivo da reflexão. Independentemente da necessidade psicológica da verdade, ou de se considerar algo como «verdadeiro», temos para nós que encontrar esse majestoso avatar é o mesmo que decidir, adentro de um plano sincrónico da história da filosofia, por uma forma de crença mais, ou menos, fundamentada, e que por hábito se aceita. Todo o conhecimento é uma forma de crença. Devemos tal ideia certamente a Platão mas principalmente a Edmund Husserl (passando por David Hume).

No caso do professor Fragata, e mesmo na sua importante obra sobre o pensamento de Husserl, pretendemos que considerar tão-só a realidade fáctica como o verdadeiro fundamento da filosofia, não resolve a questão que se subentende nesse fundamento. E a questão é o princípio da causalidade. Para o nosso autor, admitir apenas a exterioridade ou a prioridade ôntica do objeto em relação à consciência, e considerar todas as coisas somente enquanto «mero» correlato ou significado da consciência, como única forma de encontrar a razão fundamentadora dos dados sensíveis determinantes, é também "prescindir da consciência em si daquilo que se significa», e é mutilar o «princípio universal da causalidade». ${ }^{63}$

Com efeito, Husserl ${ }^{64}$ terá desprezado algumas razões, nomeadamente a propósito do problema teleológico (na ordem dos factos), da história

${ }^{63}$ Cf. FHF, pp. 257-258.

${ }^{64}$ Nomeadamente no capitulo IV das Ideias I, dedicado às reduções fenomenológicas, $\S 58$ por exemplo. 
humana (das produções culturais) e da consciência religiosa (a saber, «aquelas que adotam a forma de um motivo suscetivel de fornecer um fundamento racional»), para melhor poder estudar a consciência pura. E assim colocou «fora de circuito» o absoluto do ser transcendente e tornou-o imanente ao cogito, se bem que de modo mediato (mas não se identificando com ele, como o ego da cogitatio), ao mesmo tempo que admitiu claramente a desigualdade entre o «fundamento» e a «causa» - não no sentido de uma «causalidade de coisa» (Dinglichkausalen) - explicando que o «problema do fundamento» é apenas colocado como base não dos factos enquanto tais (facticidade) mas dos «valores possíveis e reais» que necessariamente se manifestam segundo uma ordem crescente até ao infinito. Nesta ordem de razões, o filósofo não poderia enveredar, como se torna óbvio, pela busca do fundamento enquanto ser transcendente, o que, eventualmente, se tornará lamentável para uma orientação escolástica da filosofia.

O objetivo de fazer da filosofia um proficuo campo teórico para a clarificação da riquíssima herança medieval da escolástica, tornou-se uma sedução para alguns filósofos. Um dos mais importantes exemplos é, no nosso ponto de vista, o da famosa assistente de Husserl, nos anos de 1917 a 1919, a notável judia Edith Stein, infelizmente assassinada pelos nazis em Auschwitz em 1942, mas que nos deixou a sua tradução do De Veritate, de Tomás de Aquino, para alemão. Com ela se pretendeu tornar a redução fenomenológica como pressuposto para o estudo da escolástica, tratando da necessidade de se encontrar um critério para se fazer filosofia. Será este o mesmo impulso de Júlio Fragata?

No que nos concerne, a existência de um deus é a vivência consciente de deus presente de modo imanente no ato da representação. Mas o que existe como evidência é tão-só a vivência, portanto. Sabemos que a consciência nunca é insolúvel como tal mas está sempre em mira de outra coisa diferente de si. A consciência é sempre consciência de alguma coisa, de algo transcendente, seja essa real, imaginada ou fictícia - exceção feita ao absurdo ou aquilo a que chamámos, noutro sítio, ${ }^{65}$ o horizonte de impossibilidade da imaginação ou da representação, por exemplo, um quadrado redondo, uma superfície sem cor para utilizarmos alguns exemplos do próprio Husserl. A crença da consciência queda-se no sinal do absurdo. O cogito não se funda em Deus, no infinito. $\mathrm{O}$ infinito pertence ao ser relativo da consciência ela mesma. Todo o conhecimento é visão de uma essência de modo absoluto sem reconhecer a existência de um universo separado de essências.

Ademais, na sua Filosofia da Aritmética, Husserl refere a grande distância que separa as representações reais (wirklichen) das representações sim-

${ }^{65}$ No nosso estudo, A Imaginação Material. Lisboa: Universitária Editora, 2000. 
bólicas (como Deus, coisa exterior, etc.) e dos conceitos contraditórios (como ferro de pau, etc). E ainda que o «atualmente infinito», como o conceito de Deus, é incompreensível, já que pressupõe uma «capacidade psíquica atualmente infinita». ${ }^{66}$ Avancemos, ainda, com a ideia husserliana que Deus deriva de um processo geral de idealização procedente da Filosofia: uma vez logicizado, torna-se portador do logos absoluto (uma ideia patente na inesperadamente famosa Conferência de Viena de 1935).

Por outro lado, blasfémia foi termo que não entrou no vocabulário husserliano. Melhor, a «anexação» do pensamento às igrejas cedo foi pelo filósofo repudiada. Na verdade, posso ser consciente do meu desejo de uma quimera sem que ela exista externamente. A decisão da vontade, e não, entenda-se, dos dados da inteligência, torna essa operação num momento elícito (para empregar um termo algumas vezes usado pela Escolástica). Enfim, o desejo ainda é uma forma intencional de viver um objeto, não a sua prova ontológica.

Mas este seria um tema para um estudo outro que não o presente. Com efeito, estamos, a todos os níveis (macro e micro sistémicos, biológicos e psicológicos), ironicamente condenados à incompletude, eventualmente a um sentimento de perda como resultado da própria impossibilidade lógica da nossa razão em considerar e demonstrar todas (?) as variáveis ao mesmo tempo, desde os pensamentos imaginados, como a morte por exemplo, até às mais físicas, como a causa primeira do universo.

${ }^{66}$ Cf. Hua XII, Philosophie der Arithmetik, pp. 340-373; tradução de António Fidalgo, Da Lógica dos Sinais (Semiótica). Universidade da Beira Interior. In: http://ubista.ubi. $\mathrm{pt} \sim$ comum/fidalgo-husserl-semiotik.html (consultado em 10.02.2006). 


\section{APÊNDICE}

\section{ORGANOGRAMA I}

\section{A INTUIÇÃO DOS OBJECTOS}

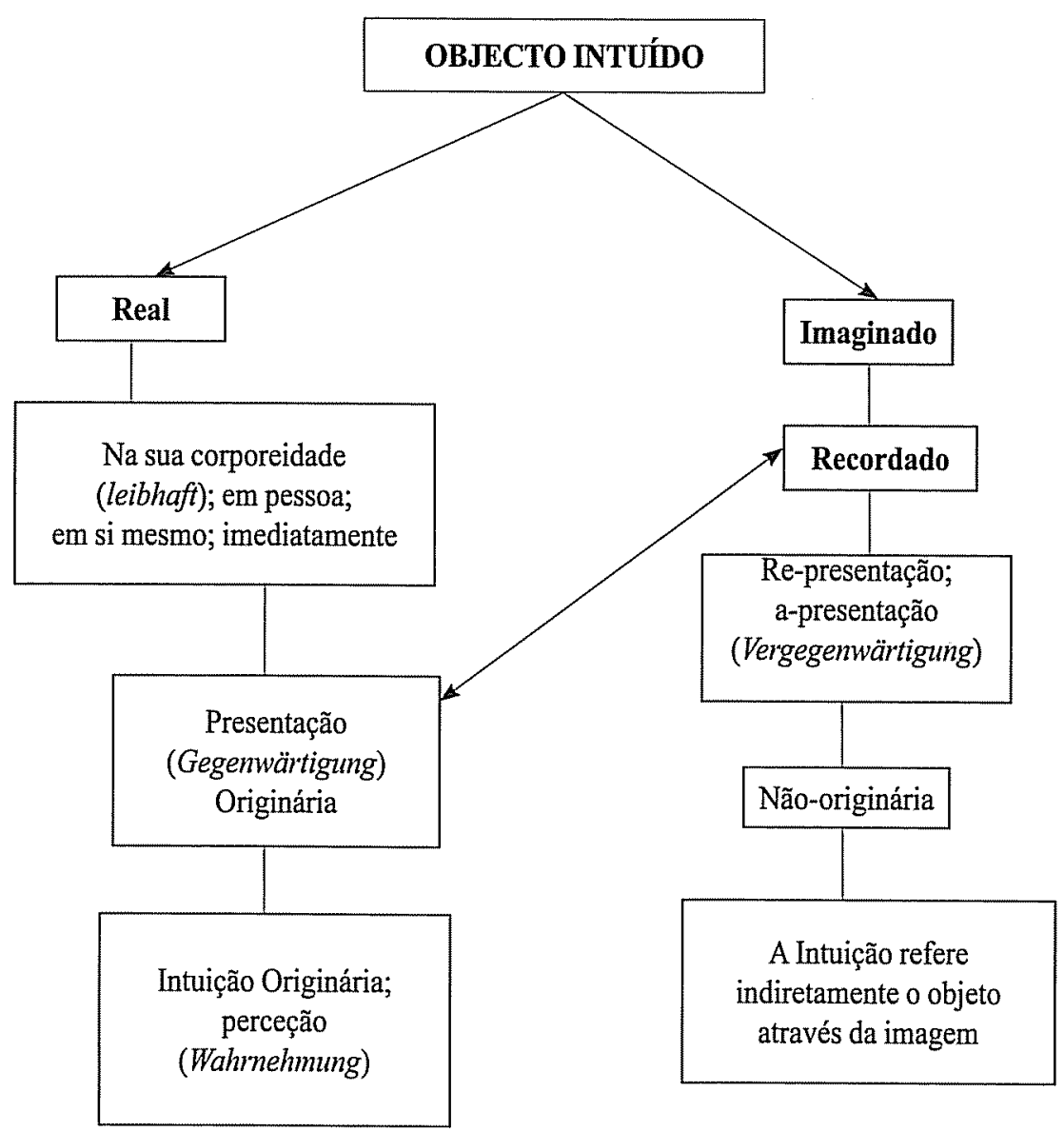




\section{ORGANOGRAMA II}

\section{OBJECTOS E INTENCIONALIDADE}

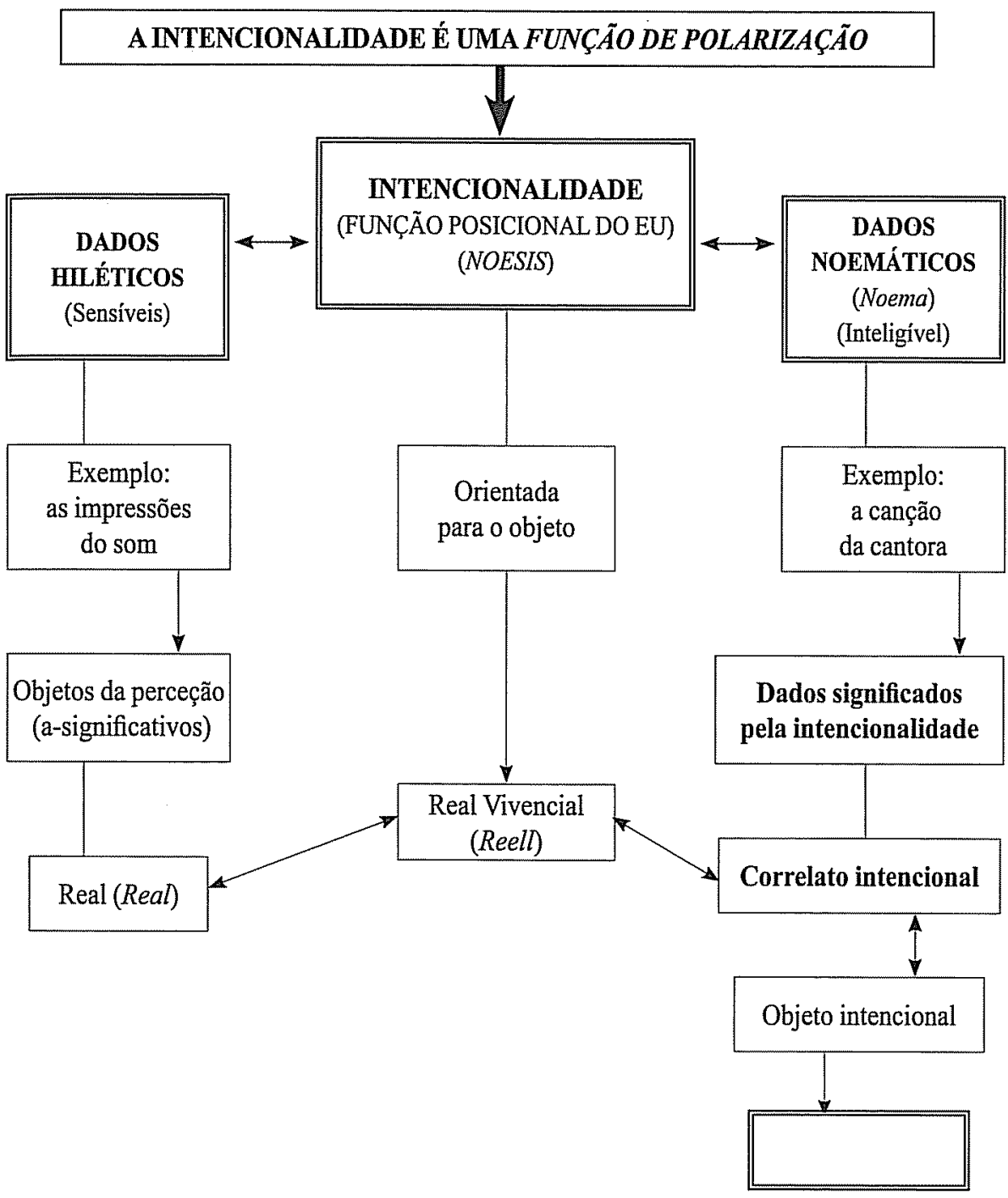




\section{ORGANOGRAMA III}

\section{NOESIS-NOEMA-OBJETO}

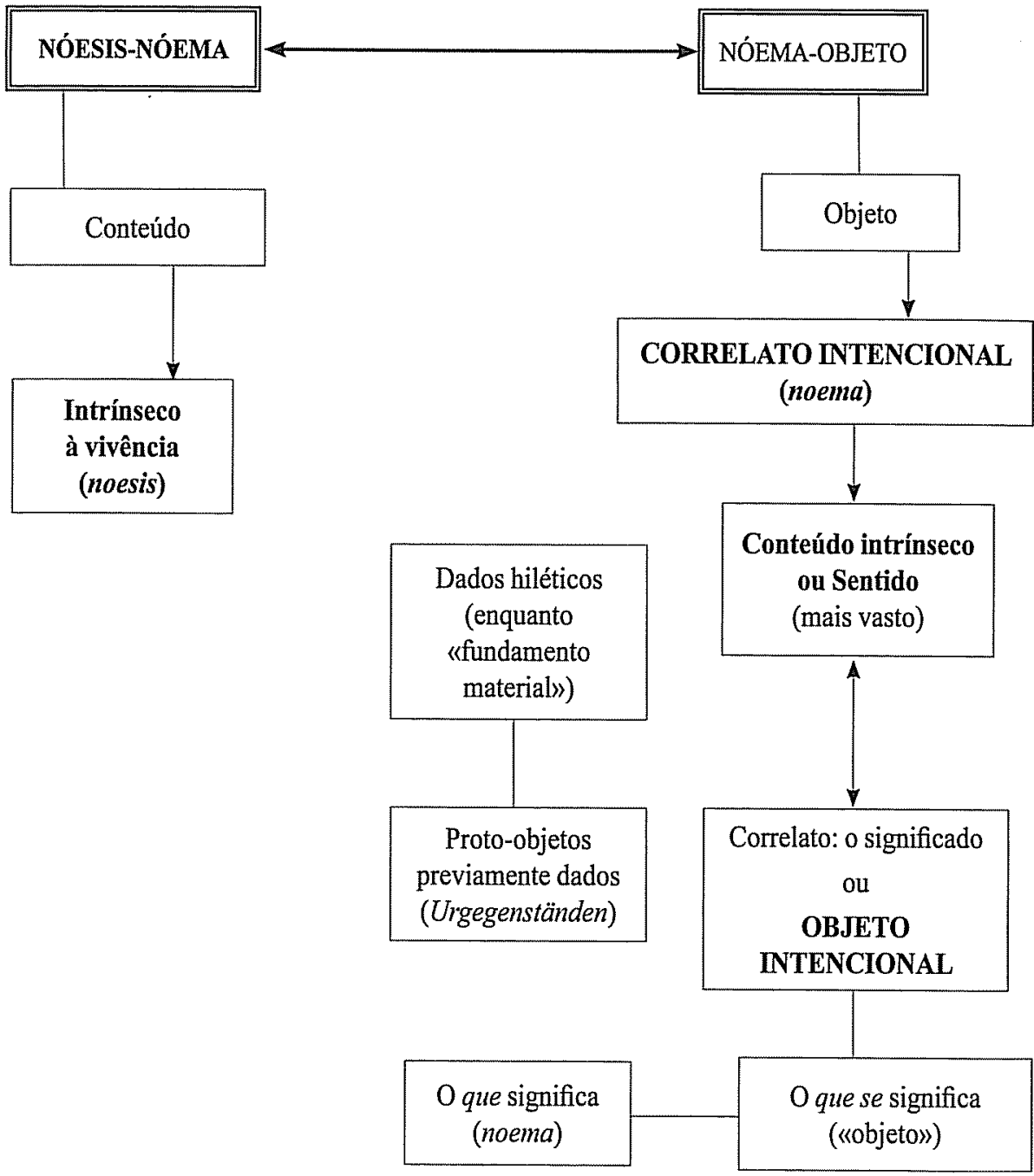




\section{ORGANOGRAMA IV}

\section{OBJECTO REAL P OBJECTO INTENCIONAL}

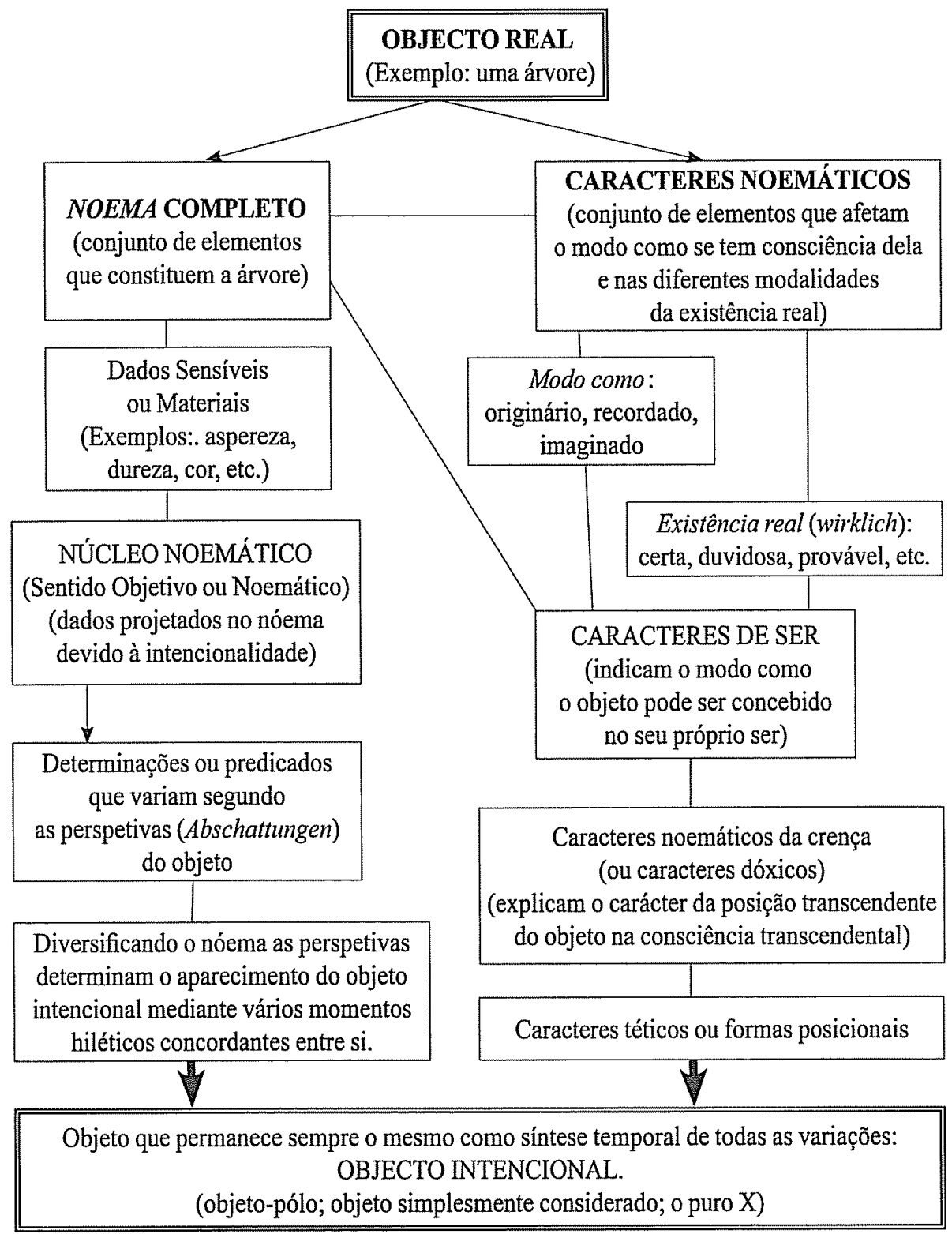




\begin{abstract}
Theologian-philosopher, Júlio Moreira Fragata, has defended in 1954 his graduation (degree) as a doctor at the Gregorian University, his thesis entitled The Phenomenology of Husserl as foundation of the Philosophy. Among this author's varied works, this one is the work which we had set out, given its importance for the phenomenology in Portugal. Besides, our study is aimed to be a pedagogical support and for the least exercised in these subjects, it is a light introduction to the phenomenological thought.

Divided in two parts: «Fragatian Presentation of Edmund Husserl's phenomenology» and «Some considerations on the fragatian conception of Edmund Husserl's phenomenology», this text still intends to explain that the true foundation of the philosophy, for the author, is the phenomenology, this means, the direct observation of that which shows itself to the conscience through the evidence of the things, in spite of his theological concerns.
\end{abstract}

